\title{
The comparison of three models applied \\ to the analysis of a three-factor trial on hybrid maize (Zea mays L.) cultivars
}

\author{
Piotr Szulc $^{1}$, Iwona Mejza², Katarzyna Ambroży-Deręgowska², \\ Kamila Nowosad ${ }^{3}$, Jan Bocianowski ${ }^{2}$ \\ ${ }^{1}$ Department of Agronomy, Poznań University of Life Sciences, Dojazd 11, \\ 60-632 Poznań, Poland, e-mail: pszulc@up.poznan.pl, \\ ${ }^{2}$ Department of Mathematical and Statistical Methods, Poznań University of Life Sciences, \\ Wojska Polskiego 28, 60-637 Poznań, Poland, e-mails: ambrozy@ up.poznan.pl; \\ imejza@up.poznan.pl, jboc@up.poznan.pl, \\ ${ }^{3}$ Department of Genetics, Plant Breeding and Seed Production, Wrocław University of \\ Environmental and Life Sciences, Grunwaldzki 24A, 53-363 Wrocław, Poland, \\ e-mail: kamila.nowosad@up.wroclaw.pl
}

\begin{abstract}
SUMMARY
The aim of this paper is to present the comparison of three models applied to the analysis of a one-year study of protein yield for two types of hybrid maize cultivars under different forms of nitrogen fertilizer and doses of magnesium. The field trial was conducted in 2010 at the Agricultural Experimental Station in Swadzim (Poland). The results obtained were analyzed in terms of three randomization-derived models of observations. Consideration was given to three mixed systems, which are combinations of split-plot design, split-block design and randomized complete block design. The relative efficiency of the designs with respect to estimation of some comparisons among treatment combination effects was examined. Particular attention was paid to the interaction between cultivars and nitrogen fertilization.
\end{abstract}

Key words: magnesium, protein yield, randomized complete block design, relative efficiency, types of nitrogen fertilizer, split-block design, split-plot design, Zea mays L.

\section{Introduction}

"Agricultural field experiments are subject to errors due to the multiplicity of causes, many of which are beyond the control of the experimenter. One of the greatest sources of error in field experiments is that due to the heterogeneity of the soil. Likewise, studies of specially designed experiments have revealed that 
size and shape of plots affect the experimental error in field trials." (see LeClerg et al., 1962).

It is not possible here to discuss comprehensively all problems related to field layout. We consider only some field techniques as efficient types and arrangements of plots used in three-factor experiments. Three popular field experimental designs are presented in order to consider statistical consequences in general and particular analyses.

The aim of this paper is to present the comparison of three models applied to the analysis of a one-year study of mean protein yield for two types of hybrid maize cultivars under different forms of nitrogen fertilizers and doses of magnesium (section 2). The order of the factors, and their importance, were determined before carrying out the experiment. Additionally, the comparison of three models applied to the analysis of three-factor trial on hybrid maize (Zea mays L.) cultivars is presented. The experimental results were analyzed in terms of three randomization-derived models of observations. These models are derived from randomization procedures applied depending on the designs chosen for the one-year trial. Consideration was given to three mixed designs, which are combinations of two different systems such as split-plot design, split-block design and randomized complete block design.

The following are considered:

- the split-split-plot (SSP) design, which is a combination of two different splitplot (SP) designs \{symbolically $[(A \rightarrow B) \rightarrow C]$ \};

- the split-plot design for three factors as the combination of a randomized complete block (RCB) design and another SP design (symbolically $[A B \rightarrow C])$; and

- the split-plot $\times$ split-block (SPSB) design $\{$ symbolically $[A \times(B \rightarrow C)]\}$, where the symbol " $\rightarrow$ " denotes nesting and " $\times$ " a cross of the factors.

All mixed designs require crossed or/and nested structures of units within blocks in the experiment (section 3); see also Ambroży and Mejza (2012). For each of them an analysis of variance and Tukey's test were performed, particularly for nitrogen fertilizer and maize cultivar interaction effects. The relative efficiency 
of the considered designs with respect to estimation of some comparisons among treatment combination effects using stratum estimates of variance errors (except for sampling errors) was examined. Attention was paid to the appropriate relationships between them. In the statistical analysis all calculations were performed using the STATISTICA 12 package and Excel.

\section{Experiment}

The field trial was carried out in the Department of Agronomy of Poznan University of Life Sciences, in the fields of the Research and Education Unit in Swadzim $\left(52^{\circ} 26^{\prime} \mathrm{N}, 16^{\circ} 45^{\prime} \mathrm{E}\right)$ in the 2010 vegetation season. The experiment was conducted in a split-split-plot design with three experimental factors, in four field replications (blocks). The first-order factor $(A)$ was six levels $(s=6)$ of forms of nitrogen fertilizers (Table 1, see Szulc and Bocianowski, 2012), the second-order factor $(B)$ was two levels $(t=2)$ of magnesium at doses of $0 \mathrm{~kg} \mathrm{MgO} \mathrm{ha}^{-1}$ and $25 \mathrm{~kg} \mathrm{MgO} \mathrm{ha}{ }^{-1}$, and the third-order factor $(C)$ was two $(w=2)$ maize cultivar types: ES Palazzo and ES Paroli stay-green (SG). The harvested plot was 15.4 $\mathrm{m}^{2}$. The same mineral fertilization was used in the year of the research before the

Table 1. Characteristics of levels for the first-order factor

\begin{tabular}{|c|c|c|c|c|c|}
\hline $\begin{array}{l}\text { Trade name of } \\
\text { nitrogen fertilizer }\end{array}$ & $\begin{array}{l}\text { Chemical } \\
\text { formula }\end{array}$ & $\begin{array}{l}\text { Nitrogen } \\
\text { content } \\
{[\%]}\end{array}$ & $\begin{array}{c}\text { Contents } \\
\text { of other } \\
\text { components } \\
{[\%]}\end{array}$ & $\begin{array}{l}\text { Nitrogen } \\
\text { dose }[\mathrm{kg} \\
\left.\mathrm{N} \cdot \mathrm{ha}^{-1}\right]\end{array}$ & $\begin{array}{c}\text { Release } \\
\text { rate }^{\#}\end{array}$ \\
\hline Ammonium nitrate & $\mathrm{NH}_{4} \mathrm{NO}_{3}$ & 34 & - & 120 & + \\
\hline Ammonium sulfate & $\left(\mathrm{NH}_{4}\right)_{2} \mathrm{SO}_{4}$ & 21 & $24 \mathrm{~S}$ & 120 & - \\
\hline Urea & $\mathrm{CO}\left(\mathrm{NH}_{2}\right)_{2}$ & 46 & - & 120 & - \\
\hline Canwil nitro-chalk & $\begin{array}{l}\mathrm{NH}_{4} \mathrm{NO}_{3}+ \\
+\mathrm{CaCO}_{3}+ \\
+\mathrm{MgCO}_{3}\end{array}$ & 27 & $\begin{array}{l}4 \mathrm{MgO} \\
7 \mathrm{CaO}\end{array}$ & 120 & + \\
\hline $\begin{array}{l}\text { Ammonium nitrate } \\
(50 \% \text { dose of } \mathrm{N})+ \\
\text { urea }(50 \% \text { dose of } \mathrm{N})\end{array}$ & $\begin{array}{l}\mathrm{NH}_{4} \mathrm{NO}_{3}+ \\
\mathrm{CO}\left(\mathrm{NH}_{2}\right)_{2}\end{array}$ & 40 & - & 120 & $-/+$ \\
\hline
\end{tabular}


experiment began: $120 \mathrm{~kg} \mathrm{~N} \cdot \mathrm{ha}^{-1}$ (according to the level of the first-order factor), $80 \mathrm{~kg} \mathrm{P}_{2} \mathrm{O}_{5} \mathrm{ha}^{-1}$ in the form of granular triple superphosphate $46 \% \mathrm{P}_{2} \mathrm{O}_{5}$, and $120 \mathrm{~kg} \mathrm{~K}_{2} \mathrm{O} \mathrm{ha}^{-1}$ in the form of $60 \%$ potassium salt. Magnesium was used in the form of kieserite $\left(25 \% \mathrm{MgO}, 50 \% \mathrm{SO}_{3}-20 \% \mathrm{~S}\right)$.

The soil content of phosphorus, potassium and magnesium in the year of the research was as follows: $36.1 \mathrm{mg} \mathrm{P} \mathrm{kg}^{-1}$ of soil; $45.6 \mathrm{mg} \mathrm{K} \mathrm{kg}^{-1}$ of soil; $34.0 \mathrm{mg}$ $\mathrm{Mg} \mathrm{kg}^{-1}$ of soil. A pH of 7.6 was determined in $1 \mathrm{M} \mathrm{KCl}$ solution. Nitrogen content in grain was assessed using the Kjeldahl method with a Kjeltec ${ }^{\mathrm{TM}} 2200$ FOSS device. The nitrogen content was multiplied by 6.25 to obtain the protein content of the grain. Protein yield was established by multiplying the protein content and dry grain yield.

\section{Statistical analysis and results}

The original trial was conducted in an SSP design in four blocks $(b=4)$. Every block consists of $s t w=v=24$ plots, and the number of observations from the experiment is $n=b v=96$. The appropriate material (field) structure is described in section 3.1. One-way analysis of variance (ANOVA) for three factors, followed by Tukey's test for $A \times C$ type interaction, was performed. Statistical inference was used to test hypotheses of lack of effect of the forms of nitrogen fertilizers, magnesium doses, types of maize cultivars and all interactions on the protein yield. Then, for comparison, the same data were analyzed twice under mixed linear models as data from an SP design (for three factors) and SPSB design. The appropriate field structures for both designs are also described in section 3.1. Since the units have to be randomized before they enter the experiment, we have three different randomization schemes depending on the experimental design. They all lead to mixed linear models of observations with fixed treatment effects and random effects of blocks and other units inside blocks depending on the design. 


\subsection{Field structure}

I. In the SSP design it is assumed that the experimental material (field) is divided into $b=4$ blocks with $s=6$ whole plots. Then, each whole plot is divided into $t=2$ subplots and each subplot is divided into $w=2$ sub-subplots. Here the whole plots correspond to the levels of factor $A$ (forms of nitrogen fertilizers), the subplots correspond to the levels of factor $B$ (doses of magnesium), and the sub-subplots accommodate the levels of factor $C$ (maize cultivars). Hence the third factor is arranged in a split-plot design in relation to the whole plot and subplot treatment combinations (i.e. combinations of the levels of factor $A$ and factor $B$, which are also arranged in a split-plot design). In the experiment, a fourstep randomization of units in the order [blocks $\rightarrow$ whole plots $\rightarrow$ subplots $\rightarrow$ sub-subplots] is performed.

It can be noted that there are three plot sizes (inside blocks) corresponding to the whole plot, the subplot and the sub-subplot. So in the SSP design there are three levels of precision of estimation of various comparisons among the treatment combination effects.

II. In the SP design (for three factors) it is assumed that the experimental material (field) is divided into $b=4$ blocks with $s t=12$ whole plots. Then, each whole plot is divided into $w=2$ subplots. Here the whole plots correspond to combinations of the levels of factors $A$ and $B$ (fertilizers), and the subplots accommodate the levels of factor $C$ (maize cultivars). Hence the third factor $C$ is arranged in a split-plot design in relation to combinations of the levels of factors $A$ and $B$, which are successively arranged in an RCB design. In the experiment a three-step randomization of units [blocks $\rightarrow$ whole plots $\rightarrow$ subplots] is performed.

It can be noted that there are two plot sizes (inside blocks) corresponding to the whole plot and the subplot. Hence in the SP design there are two levels of precision of estimation of various comparisons among the treatment combination effects.

III. In the SPSB design every block forms a row-column design with $s=6$ rows and $t=2$ columns of the first order, called I-columns for short. Then each 
I-column has to be split into $w=2$ columns of the second order (called II-columns). In this case, the rows correspond to the levels of factor $A$ (forms of nitrogen fertilizers), the I-columns correspond to the levels of factor $B$ (doses of magnesium), and the II-columns accommodate the levels of factor $C$ (maize cultivars). Here, factor $C$ is in a split-plot design in relation to factor $B$ (which in turn is in a split-block design with factor $A$ ). In the experiment a four-step randomization of units [blocks $\rightarrow$ rows $\times$ (I-columns $\rightarrow$ II-columns)] is performed.

Five plot sizes (inside blocks) correspond to the row, the I-column, the II-column, the whole plot, which is an intersection plot between the row and the I-column, and the subplot, which in turn is an intersection plot between the row and the II-column. Hence in the SPSB design there are five levels of precision of estimation of comparisons among the treatment combination effects.

Generally, the stratum precision of the estimation is a measure of the inverse of the stratum variance of error (under full stratum efficiency of the design). It can be assumed (except for sampling errors) that the estimates of the stratum variance errors in the designs satisfy certain inequalities (see e.g. Ambroży et al., 2014). These relationships can be observed (except for sampling errors) in the presented tables of ANOVA data (Tables 2-4).

Table 2. Results of ANOVA for the type SSP design

\begin{tabular}{lccccc}
\hline \multirow{2}{*}{ Source of variation } & \multicolumn{5}{c}{ Protein yield } \\
\cline { 2 - 6 } & d.f. & SS & MS & $F$-Statistic & $p$ \\
\hline Blocks & 3 & 11998 & 3999 & & \\
$A-$ Forms of fertilizer & 5 & 277701 & 55540 & $55.87 * *$ & 0.0000 \\
Error 1 & 15 & 14911 & 994 & & \\
\hline$B-$ Magnesium & 1 & 7719 & 7719 & $9.84^{* *}$ & 0.0057 \\
$A \times B$ & 5 & 30977 & 6195 & $7.89^{* *}$ & 0.0004 \\
Error 2 & 18 & 14124.96 & 784.72 & & \\
\hline$C-$ Maize cultivar types & 1 & 1317753 & 1317753 & $671.9^{* *}$ & 0.0000 \\
$A \times C$ & 5 & 69829 & 13966 & $7.12^{* *}$ & 0.0001 \\
$B \times C$ & 1 & 4909 & 4909 & 2.5 & 0.1224 \\
$A \times B \times C$ & 5 & 10630 & 2126 & 1.08 & 0.3857 \\
Error 3 & 36 & 70605 & 1961 & & \\
\hline Total & 95 & 1831156 & & & \\
\hline$* *$ significant at $p<0.01$ & \multicolumn{7}{|c}{}
\end{tabular}


Table 3. Results of ANOVA for the $(A B \rightarrow C)$ type SP design

\begin{tabular}{lccccc}
\hline \multirow{2}{*}{ Source of variation } & \multicolumn{5}{c}{ Protein yield } \\
\cline { 2 - 6 } & d.f. & SS & MS & $F$-Statistic & $p$ \\
\hline Blocks & 3 & 11998 & 3999 & & \\
$A-$ Forms of fertilizer & 5 & 277701 & 55540 & $63.12^{* *}$ & 0.0000 \\
$B-$ Magnesium & 1 & 7719 & 7719 & $8.77 * *$ & 0.0056 \\
$A \times B$ & 5 & 30977 & 6195 & $7.04 * *$ & 0.0001 \\
Error 1 & 33 & 29036 & 879.88 & & \\
\hline$C-$ Maize cultivar types & 1 & 1317753 & 1317753 & $671.9 * *$ & 0.0000 \\
$A \times C$ & 5 & 69829 & 13966 & $7.12^{* *}$ & 0.0001 \\
$B \times C$ & 1 & 4909 & 4909 & 2.5 & 0.1224 \\
$A \times B \times C$ & 5 & 10630 & 2126 & 1.08 & 0.3857 \\
Error 2 & 36 & 70605 & 1961 & & \\
\hline Total & 95 & 1831156 & & & \\
\hline$* *$ significant at $p<0.01$ & \multicolumn{7}{|c}{}
\end{tabular}

Table 4. Results of analysis of variance for the type SPSB design

\begin{tabular}{lccccc}
\hline \multirow{2}{*}{ Source of variation } & \multicolumn{5}{c}{ Protein yield } \\
\cline { 2 - 6 } & d.f. & SS & MS & $F$-Statistic & $p$ \\
\hline Blocks & 3 & 11998 & 3999 & & \\
$A$ - Forms of fertilizer & 5 & 277701 & 55540 & $55.87 * *$ & 0.0000 \\
Error 1 & 15 & 14911 & 994 & & \\
\hline$B$ - Magnesium & 1 & 7719 & 7719 & 5.49 & 0.1010 \\
Error 2 & 3 & 4220 & 1407 & & \\
\hline$A \times B$ & 5 & 30977 & 6195 & $9.39 * *$ & 0.0003 \\
Error 3 & 15 & 9905 & 660 & & \\
\hline$C-$ Maize cultivar types & 1 & 1317753 & 1317753 & $219.61 * *$ & 0.0000 \\
$B \times C$ & 1 & 4909 & 4909 & 0.82 & 0.4001 \\
Error 4 & 6 & 36002 & 6000.3 & & \\
\hline$A \times C$ & 5 & 69829 & 13966 & $12.11^{* *}$ & 0.0000 \\
$A \times B \times C$ & 5 & 10630 & 2126 & 1.84 & 0.1346 \\
Error 5 & 30 & 34602 & 1153 & & \\
\hline Total & 95 & 1831156 & & & \\
\hline$* *-$ significant at $p<0.01$ & & & & \\
& & & & & \\
\end{tabular}

\subsection{Results}

The final results of analysis of variance, depending on the considered design, are given in Tables 2-4. Then, for illustration, a particular analysis in the SSP design related to some comparisons of interaction effects is presented (Table 5, Fig. 1). It can be shown that in the particular analysis similar conclusions were obtained 
for the SP design and SSP design. The difference relates mainly to the precision of the comparison estimation.

The results presented in Tables 2-4 indicate nonsignificant two-way interaction between magnesium and maize cultivar types, and three-way interaction between forms of fertilizer, magnesium and maize cultivar types. Other results indicate highly significant differences among the main effects of types of maize and the remaining interaction effects, except for one case: in the analysis of variance for the SPSB design (Table 4) the $F$ test indicated no significant difference between the main effects of magnesium. This is a result of the small number of degrees of freedom for Error 2.

Four homogeneous groups of the $A \times C$ interaction were distinguished on the basis of Tukey's honestly significant differences (HSDs) (Table 5). It may be noted that all forms of fertilizer significantly increased the protein yield of ES Paroli. The largest value of protein yield was observed for the combination ammonium sulfate and ES Paroli (880.0062 $\left.\mathrm{kg} \mathrm{ha}^{-1}\right)$. It significantly differs from

Table 5. Tukey's HSD test for $A \times C$ interaction effects (Homogeneous groups, $\alpha=0.01$, Error $3-\mathrm{MS}=1961$; d.f. $=36$ )

\begin{tabular}{lcc}
\hline $\begin{array}{l}\text { Factor } A \\
\text { Forms of fertilizer }\end{array}$ & $\begin{array}{c}\text { Factor } C \\
\text { Maize cultivar types }\end{array}$ & $\begin{array}{c}\text { Protein yield } \\
\text { means }{ }^{\mathrm{a}}\left[\mathrm{kg} \mathrm{ha}^{-1}\right]\end{array}$ \\
\hline No fertilizer & ES Palazzo & $518.7473 \mathrm{a}$ \\
Ammonium nitrate & ES Palazzo & $577.7122 \mathrm{ab}$ \\
Ammonium nitrate + urea & ES Palazzo & $582.8718 \mathrm{ab}$ \\
Urea & ES Palazzo & $595.3913 \mathrm{ab}$ \\
Canwil nitro-chalk & ES Palazzo & $595.6783 \mathrm{ab}$ \\
Ammonium sulfate & ES Palazzo & $601.1734 \mathrm{ab}$ \\
\hline No fertilizer & ES Paroli & $650.1017 \mathrm{~b}$ \\
Ammonium nitrate & ES Paroli & $778.5062 \mathrm{c}$ \\
Canwil nitro-chalk & ES Paroli & $837.3082 \mathrm{~cd}$ \\
Ammonium nitrate + urea & ES Paroli & $852.0623 \mathrm{~cd}$ \\
Urea & ES Paroli & $879.5162 \mathrm{~d}$ \\
Ammonium sulfate & ES Paroli & $880.0062 \mathrm{~d}$ \\
\hline${ }^{a}$ Means followed by the same letter are not significantly & \\
different at the 1\% level. & &
\end{tabular}




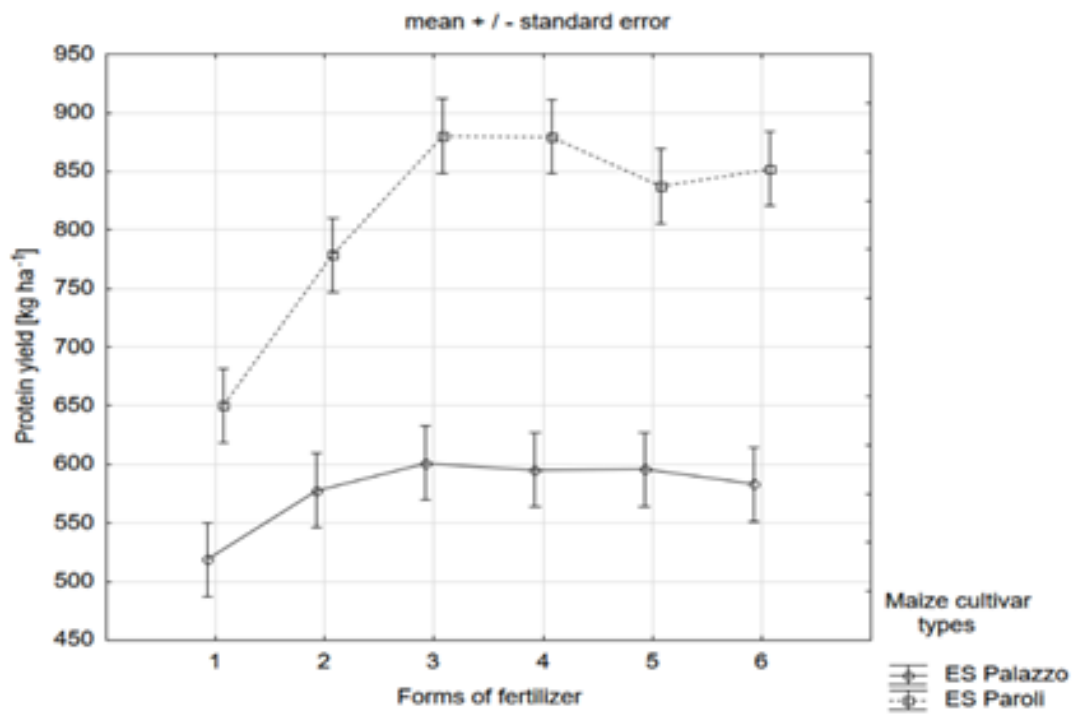

Figure 1. Mean protein yield of two types of maize cultivar with six forms of fertilizer.

the mean yield of the combination ammonium nitrate and ES Paroli $(778.5062 \mathrm{~kg}$ $\mathrm{ha}^{-1}$ ), whereas protein yield means for ES Palazzo were statistically the same for all forms of fertilizer - group 1. We can deduce that the maize cultivar types do not respond equally to the applied forms of fertilizer (Table 5, Fig. 1).

\subsection{Relative efficiency}

In Ambroży et al. (2014) the relative efficiency of an SSP design to an SPSB design was shown. In the same way, efficiency comparisons between those designs and an SP design can be presented. The results indicate that design preferences in the estimation and analysis of some comparisons among the main effects of factors and interaction effects are similar to those given in Table 6. In our example, the letter $\boldsymbol{a}$ denotes for instance that the SPSB design is more effective than other designs in the estimation and analysis of comparisons of the interaction effects of types $A \times B, A \times C$ and $A \times B \times C$. 
Table 6. Design preferences in the estimation and analysis of some groups of comparisons

\begin{tabular}{cccc}
\hline Sources & SSP & SPSB & SP $(A B \rightarrow C)$ \\
\hline$A$ & $b$ & $b$ & $a$ \\
$B$ & $a$ & $c$ & $b$ \\
$A \times B$ & $b$ & $a$ & $c$ \\
$\mathrm{C}$ & $a$ & $b$ & $a$ \\
$A \times C$ & $b$ & $a$ & $b$ \\
$B \times C$ & $a$ & $b$ & $a$ \\
$A \times B \times C$ & $b$ & $a$ & $b$ \\
\hline$a, b, c-$ degrees of efficiency of the designs, in decreasing order
\end{tabular}

\section{Discussion}

The present work was stimulated by the analyzed one-year field trial with hybrid maize (Zea mays L.) cultivars, forms of nitrogen fertilizer and magnesium. The original experiment was conducted in an SSP design. The reason that this design was selected is that larger experimental units are required for factor $A$ levels (forms of fertilizer) and for factor $B$ levels (magnesium) than for factor $C$ levels (maize cultivars). Another reason is that less precision in estimation of comparisons is usually required for factors $A$ and $B$ and the interaction $A \times B$, and more for factor $C$ and other interaction effects (except for sampling errors); see e.g. Federer and King (2007).

Two additional analyses under mixed linear models were performed, concerning the split-plot $(A B-C)$ design and the split-plot $\times$ split-block design. Similarly to the SSP design, these are popular and often used in field research. It may be interesting to note that the results of ANOVA obtained for these designs may be regarded as similar. It was of interest to compare all of them with respect to their relative efficiency. The results are given in Table 6 .

We need to comment on the fact that in the considered designs not all stratum estimates of the error variance fulfill the relevant relationships. This was probably due to the heterogeneity of the experimental material (field) and the associated sampling errors. 
Finally, it should be pointed out that in this paper our considerations concerned mainly statistical aspects of the design of this experiment, and they relate to the considered designs. A practical rule, in turn, is to use an appropriate experimental design that fulfills the requirements of the experiment and enables attainment of the research objectives.

\section{REFERENCES}

Ambroży K., Mejza I. (2012): Modeling data from three-factor experiments with split units set up in designs with different block structures (in Polish). Biul. IHAR 264: 23-31.

Ambroży K., Mejza I., Mejza S. (2014): On the relative efficiency of split-split-plot design to split-plot $\times$ split-block design. Colloquium Biometricum 44: 69-78.

Federer W.T., King F. (2007): Variations on Split Plot and Split Block Experiment Designs. Wiley. New Jersey.

LeClerg E.L., Leonard W.H., Clark A.G. (1962): Field plot technique. Burgess, Minneapolis.

Szulc P., Bocianowski J. (2012): The effect of soil supplementation with different forms of nitrogen fertiliser on modification of generative yield in two different types of maize (Zea mays L.) hybrids. Polish Journal of Agronomy 11: 52-64. 